University of Nebraska - Lincoln

DigitalCommons@University of Nebraska - Lincoln

1994

\title{
A New Coccidian (Apicomplexa: Eimeriidae) in the Northern Pocket Gopher (Thomomys talpoides) and a Comparison of Oocyst Survival in Hosts from Radon-Rich and Radon-Poor Soils
}

\author{
P. G. Wilber \\ University of New Mexico \\ K. McBee \\ Oklahoma State University \\ D. J. Hafner \\ New Mexico Museum of Natural History \\ Donald W. Duszynski \\ University of New Mexico, eimeria@unm.edu
}

Follow this and additional works at: https://digitalcommons.unl.edu/parasitologyfacpubs

Part of the Parasitology Commons

Wilber, P. G.; McBee, K.; Hafner, D. J.; and Duszynski, Donald W., "A New Coccidian (Apicomplexa:

Eimeriidae) in the Northern Pocket Gopher (Thomomys talpoides) and a Comparison of Oocyst Survival in Hosts from Radon-Rich and Radon-Poor Soils" (1994). Faculty Publications from the Harold W. Manter Laboratory of Parasitology. 191.

https://digitalcommons.unl.edu/parasitologyfacpubs/191

This Article is brought to you for free and open access by the Parasitology, Harold W. Manter Laboratory of at DigitalCommons@University of Nebraska - Lincoln. It has been accepted for inclusion in Faculty Publications from the Harold W. Manter Laboratory of Parasitology by an authorized administrator of DigitalCommons@University of Nebraska - Lincoln. 


\title{
A NEW COCCIDIAN (APICOMPLEXA: EIMERIIDAE) IN THE NORTHERN POCKET GOPHER (THOMOMYS TALPOIDES) AND A COMPARISON OF OOCYST SURVIVAL IN HOSTS FROM RADON-RICH AND RADON-POOR SOILS
}

\author{
P. G. Wilber,' K. McBee, ${ }^{2}$ D. J. Hafner, ${ }^{3}$ and D. W. Duszynski' \\ ' Department of Biology, The University of New Mexico, Albuquerque, New Mexico 87131, USA \\ 2 Department of Zoology, Oklahoma State University, Stillwater, Oklahoma 74078, USA \\ ${ }^{3}$ New Mexico Museum of Natural History, Albuquerque, New Mexico 87104, USA
}

ABSTRACT: Forty (93\%) of 43 northern pocket gophers (Thomomys talpoides) from the Jemez Mountains, Sandoval County, New Mexico (USA), had coccidian oocysts in their feces when examined. We describe this parasite, Eimeria jemezi, n. sp. Sporulated oocysts were subspheroidal, 13.3 by 12.2 ( 10 to 17 by 9 to 15 ) $\mu \mathrm{m}$, with sporocysts ellipsoidal, 7.1 by 4.4 (5 to 9 by 4 to 5 ) $\mu \mathrm{m}$; micropyle and oocyst residuum were absent, but polar bodies, Stieda bodies and sporocyst residua were present. All gophers were collected from two sites of similar habitat $7 \mathrm{~km}$ apart. One site $(\mathrm{R}+$ ) had a high soil radon content ( $\geq 50$ to 70 picocuries $(\mathrm{pCi})$ per liter of air) whereas the other site $(\mathrm{R}-)$ had soils that were near average natural levels ( 1.2 to $1.6 \mathrm{pCi} / \mathrm{g}$ uranium nucleotides per gram of soil; $<1.9 \mathrm{pCi} / \mathrm{g}$ thorium nucleotides). Twenty-one (88\%) of 24 gophers from the $\mathrm{R}+$ site had coccidian oocysts in their intestines when examined, but none of these oocysts ever sporulated, whereas all $19(100 \%)$ gophers from the $\mathrm{R}$ - site had coccidian oocysts in their intestines and $16(84 \%)$ of these samples sporulated normally under laboratory conditions. The elevated radon content of the soil may have had an adverse effect on the sporulation of this coccidian while it still was intracellular within its host.

Key words: Coccidia, Eimeria jemezi, Thomomys talpoides, radon.

\section{INTRODUCTION}

The northern pocket gopher (Thomomys talpoides) has the widest distribution of any pocket gopher, ranging from Alberta to New Mexico and Arizona (USA) (Chase et al., 1984). In New Mexico it is restricted to higher elevations in the northern half of the state. It occurs from about the ponderosa pine (Pinus ponderosa) zone upward to the highest elevations where soils are sufficiently friable for burrowing activity (Findley, 1987). As part of a larger study to determine the effects of radonrich $(\mathrm{R}+)$ soils on $T$. talpoides, we compared coccidian infections in gophers trapped in a $R+$ site to those trapped in a nearby radon-poor $(\mathrm{R}-)$ site in the Jemez Mountains of New Mexico. We also describe a new species of Eimeria.

\section{MATERIALS AND METHODS}

Twenty-four gophers were collected with killtraps from July 4 to 5 from one $R+$ site located at El Cajete crater, $8.0 \mathrm{~km}$ north, $11.3 \mathrm{~km}$ east of Jemez Springs, Sandoval County, New Mexico (USA) $\left(35^{\circ} 50^{\prime} \mathrm{N}, 106^{\circ} 34^{\prime} \mathrm{W}\right)$. The $\mathrm{R}+$ site is on El Cajete pumice (El Cajete member of the Valles rhyolite), with concentrations of radonproducing thorium and uranium 4 to 5 times that of average soils (Self et al., 1988). The highly permeable nature of this pumice provided pathways for migration and accumulation of radon gas, and radon concentrations of $\geq 50$ to 70 picocuries $(\mathrm{pCi})$ per liter of air have been recorded from the living space of buildings constructed on this pumice using charcoal radon test canisters (Manchengo et al., 1991). The Environmental Protection Agency has recommended $4 \mathrm{pCi} / \mathrm{l}$ as a guideline for annual average exposure to radon for humans (RoncaBattista et al., 1987). Radon concentrations inside the plugged burrows of gophers would be at least as high, and probably much higher, than levels measured inside the relatively wellventilated living spaces of buildings.

Nineteen gophers were trapped on 6 July 1991 at a $\mathrm{R}$ - site, $7 \mathrm{~km}$ from the $\mathrm{R}+$ site, $4.8 \mathrm{~km}$ north, $17.7 \mathrm{~km}$ east of Jemez Springs, Sandoval County, New Mexico (USA) $\left(35^{\circ} 49^{\prime} \mathrm{N}, 106^{\circ} 30^{\prime} \mathrm{W}\right)$ from 4 to 6 July 1991 . The $R-$ site is on andesite of the Paliza Canyon formation. Radionucleotide levels at the $\mathrm{R}$ - site were determined from gamma spectrometric measurements of five $2-\mathrm{kg}$ soil samples collected from mounds pushed up by gopher burrowing activity. Soil assays were conducted at the Department of Physics at the New Mexico Institute of Mining and Technol- 
ogy, Socorro, New Mexico using a gamma spectrometry system, with EG\&G ORTEC GMX series gamma $\mathrm{X}$-ray high purity germanium (EG\&G ORTECH, Oak Ridge, Tennessee, USA), and analyzed with VAX/VMS Spectroscopy Application software (Canberra Nuclear Products Group, Nuclear Data Systems, Schaumburg, Illinois, USA). Uranium series radionuclide concentrations were assessed using ${ }^{210} \mathrm{~Pb},{ }^{214} \mathrm{~Pb}$, and ${ }^{214} \mathrm{Bi}$ gamma energies, assuming equilibrium conditions; thorium series radionuclide concentrations were assessed using ${ }^{208} \mathrm{Tl},{ }^{212} \mathrm{~Pb}$, and ${ }^{228} \mathrm{Ac}$ gamma energies, assuming equilibrium conditions. Based on five samples each, values for uranium series concentrations $(\bar{x}=1.5 \mathrm{pCi} / \mathrm{g}$; range $=1.4$ to $1.7 \mathrm{pCi} / \mathrm{g}$ ) and thorium series concentrations $(\bar{x}=1.7 \mathrm{pCi} / \mathrm{g}$; range $=1.6$ to $1.9 \mathrm{pCi} / \mathrm{g}$ ) were close to the upper range for typical soils ( $1.4 \mathrm{pCi} / \mathrm{g}$ ) (M. Wasiolek, pers. comm.). Further, the higher density of soil at the $\mathrm{R}$ - site would normally result in lower radon gas migration and accumulation (Manchengo et al., 1991). Thus, radon gas concentrations in gopher burrows at the $\mathrm{R}+$ site would be at least 4 to 5 times higher than those at the $\mathbf{R}$ - site, which are closer to average soil concentrations.

Fresh fecal samples were collected from the lower bowel of each gopher during necropsy and stored in $2 \%$ aqueous $(\mathrm{w} / \mathrm{v}) \mathrm{K}_{2} \mathrm{Cr}_{2} \mathrm{O}_{7}$. All methods for preparing, sporulating, and storing fecal samples, and for concentrating, measuring, and photographing oocysts were as described by Duszynski et al. (1982) and Stout and Duszynski (1983), and were identical for both sites. Measurements are in $\mu \mathrm{m}$ with size ranges in parentheses following the means. Oocysts were measured when they were 188 days old. Significance of sporulation rate between the $R+$ and R- sites was computed using the Fisher Exact Test (Zar, 1984). We have deposited a phototype (Bandoni and Duszynski, 1988) of a sporulated oocyst in the U.S. National Museum, Beltsville, Maryland, Parasite Collection (USNMPC 82825). A symbiotype (see Frey et al., 1992) (host skin + skeleton) has been deposited at the New Mexico Museum of Natural History (NMMNH 1645).

\section{RESULTS}

At the $\mathrm{R}+$ site, 21 (88\%) of 24 gophers had oocysts of a single morphotype, but none of the oocysts recovered from the intestinal contents of these hosts sporulated. At the $\mathrm{R}-$ site, all 19 gophers had coccidian oocysts in their intestinal tracts, and oocysts from $16(84 \%)$ of the 19 sporulated normally. Differences in the fre- quency of oocyst sporulation between the $\mathrm{R}+$ and $\mathrm{R}-$ sites were significant $(P<$ 0.001 ).

All coccidian oocysts recovered from hosts taken from the $R$ - site, that later sporulated, appeared to represent a new species.

Eimeria jemezi n. sp.

Oocyst spheroidal to subspheroidal (Figs. 1 to 5), wall about 1.0, composed of two layers: outer smooth, yellow, about threequarters of total thickness (Fig. 1); inner smooth, light yellow; micropyle and oocyst residuum absent; 0 to 3 (usually 1) polar bodies ( 1 to 3 by 1 to 2 ) present, highly refractile (transmitted light) (Fig. 2); sporulated oocysts $(n=50) 13.3$ by 12.2 (10 to 17 by 9 to 15 ) with length to width (L/ W) ratio 1.1 (1.0 to 1.3 ; ; sporocysts ellipsoidal, 7.1 by 4.4 ( 5 to 9 by 4 to 5 ) with L/W ratio 1.6 (1.3 to 2.2); Stieda body present (Figs. 3 and 4), but sub- and parastieda bodies absent; sporocyst residuum a rosette or several scattered granules (Figs. 3 and 4); sporozoites each with a large posterior refractile body and these orient at the top and bottom of the sporocyst (Figs. 3 to 5 ).

The oocysts were found in the northern pocket gopher (Thomomys talpoides) in Sandoval County, New Mexico, $4.8 \mathrm{~km}$ north, $17.7 \mathrm{~km}$ east of Jemez Springs. The site of infection within the host is unknown because the oocysts were collected from feces. The nomen triviale is derived from the collection locality.

\section{DISCUSSION}

Sporulated oocysts of E. jemezi resembled those of Eimeria thomomysis (Levine et al., 1957) from Thomomys bottae fulvus in Arizona; Eimeria geomydis (Skidmore, 1929) from Geomys bursarius in Nebraska, Illinois, and Missouri (USA) and from Geomys breviceps and Geomys texensi in Texas (USA) (Upton et al., 1992); and Eimeria orthogeomyos (Lainson, 1968) from Orthogeomys grandis scalops in British Honduras, Central America. They 

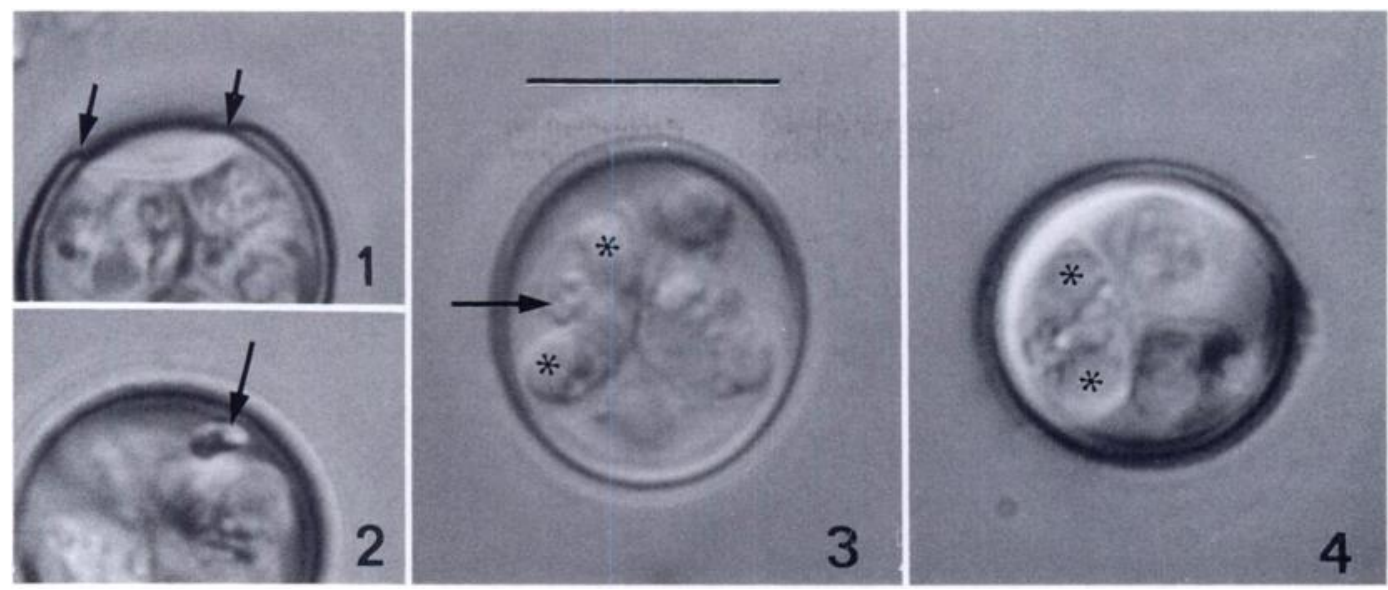

Figures 1 to 4. Photomicrographs of sporulated oocysts of Eimeria jemezi n. sp. collected from intestinal contents of Thomomys talpoides. Fig. 1. Wall of an oocyst with a section of outer layer (arrows) that has peeled off. Fig. 2. Superficial view of an oocyst with a polar body (arrow). Figs. 3, 4. Sporulated oocysts with normal variation in size and shape (subspheroidal, 3 vs. spheroidal, 4), rosette-like sporocyst residuum (arrow, 3). and large refractile bodies of sporozoites $\left({ }^{*}\right)$ that lie at the ends of each sporocyst. Note small Stieda body at pointed end of sporocysts. Bar $=10 \mu \mathrm{m}$ for all figures.

differed from E. thomomysis by being smaller ( 13.2 by 12.2 vs. 14.2 by 13.9 ), having a distinct polar body, and having a sporocyst residuum that was either a rosette or a group of large granules (versus one of small scattered granules). They differed from E. geomydis by having a highly refractile polar body, and lacking a distinctive bump on the outer wall of the oocyst. They differed from E. orthogeomyos by lacking an oocyst residuum and having a highly refractile polar body and a distinctive sporocyst residuum.

It was impossible to definitively identify to species the unsporulated oocysts from the $R+$ site, because eimerian identification is based on morphology of the sporulated oocysts, but they were similar in size ( 13.6 by $12.3 ; 10.8$ to 16.2 by 9.0 to $14.4 \mu \mathrm{m}, n=25)$ to $E$. jemezi oocysts from the $\mathrm{R}$ - site and the two sites are separated by only $7 \mathrm{~km}$. Thus, oocysts from both sites probably were the same species.

While no oocysts from the $\mathrm{R}+$ area sporulated, oocysts recovered from 16 (84\%) of 19 gophers caught on the $\mathrm{R}$ - site did sporulate. We propose that non-sporulation of oocysts from hosts taken on $\mathrm{R}+$ soils may have been due to the effect of radon either on the normal physiology of the host or directly on oocyst development while the parasite was still intracellular within the host, or both. Radon has been implicated in chromosomal aberrations of uranium miners (Brandom et al., 1972), spa house personnel (Pohl-Ruling and Fischer, 1979), rabbits (Leonard et al., 1981)

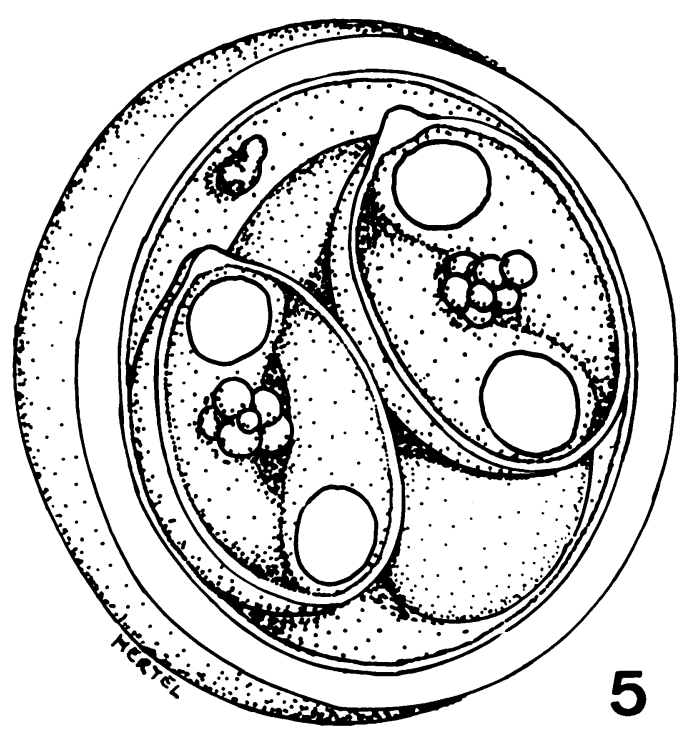

Figure 5. Line drawing of sporulated oocyst of Eimeria jemezi. Bar $=10 \mu \mathrm{m}$. 
and Sprague-Dawley rats (Poncy et al., 1980); radon in drinking water can cause chromosomal aberration in human lymphocytes (Stenstran et al., 1979). Little is known about genetic effects of radon exposure in invertebrate systems but Sperlich et al. (1967) found increased frequencies of dominant lethal mutations in Drosophila melanogaster. Oocysts from the $\mathrm{R}+$ site had normally developed walls indicating apparently successful asexual and sexual reproduction within gopher intestinal epithelium. Failure to complete development upon release into the environment may indicate chromosomal aberration within the sporoplasm that prevented sporulation. Very little is known about reproductive or developmental effects of radon in any animal model.

The $R+$ site is a 170,000 to 130,000 year-old volcanic caldera (Self et al., 1988) containing friable pumice soils that are both high in radon and conducive to radon gas migration and accumulation. On the caldera slope there are less friable, shallower soils. Gophers are highly territorial, fossorial, and prefer friable soil (Findley, 1987); thus, established gophers tend to live in the deeper soils, while immigrants are confined to the fringes (Patton and Feder, 1981). On the R+ site, 21 (88\%) of 24 gophers were infected with coccidia, but none of the oocysts sporulated. If no viable oocysts are produced, coccidia infections should soon become locally extinct. However, the high prevalence of infection suggests that gophers living on the crater floor may be regularly infected by ingesting sporulated oocysts from juveniles immigrating from $\mathbf{R}-$ areas where oocyst development was not impaired. Additionally, high prevalence also may indicate low immunogenicity and repeated or persistent infections in individuals as in at least two squirrel (Spermophilus) systems (Seville et al., 1992; Wilber et al., 1994). This could result in long-term oocyst output even on the $R+$ site and a very low number of the abnormal oocysts may sporulate within the burrows. Gophers defecate in dead-end feeding tunnels, and then wall them up (Howard and Childs, 1959), producing a moist sporulation chamber. Millions of oocysts commonly are produced during a single coccidial infection and oocysts apparently can remain viable in the soil for extended periods of time (Dorney, 1962). Since gophers dig with their teeth, occasionally invade adjoining burrows, and utilize abandoned burrows (D. J. Hafner, unpubl.), ample opportunity for infection with and dispersal of oocysts exists. Finally, since dispersers moving into the radon area were likely to be forced to build burrows in the less friable soil on the caldera slope, uphill of more established gopher sites, some oocysts might have washed downhill with precipitation runoff. It is possible that the two sites harbored different coccidian parasites. However, the sites were located only $7 \mathrm{~km}$ apart, so it was likely that gopher dispersal has produced similar parasite faunas in both groups. It also is possible the two sites supported genetically distinct gopher populations. Genetic similarity between the two host populations has not been established, but Nevo et al. (1974) reported identical karyotypes (non-preferentially stained) from two populations of $T$. talpoides $11 \mathrm{~km}$ apart in the Jemez mountains. The two sites were within the theoretical dispersal distance of gophers (Daly and Patton, 1990) and, although individuals from one site may not move as far as the other site, a breeding continuum probably existed between the two groups. This would result, at least, in the indirect transfer of genetic information between populations. Tissue from these gophers (heart, liver, kidney), preserved in liquid nitrogen for protein electrophoresis, as well as chromosomes collected from bone marrow, are now being analyzed to determine the genetic relatedness of these two populations.

\section{ACKNOWLEDGMENTS}

We thank L. Couch for technical assistance and M. L. Theis, K. M. Theis, S. L. Hedinger and R. A. Grantham for field assistance. We also 
thank J. W. Hawley and M. Wasiolek, New Mexico Institute of Mining and Technology, for analysis of soil samples. This work was supported, in part, by U.S. Air Force grant No. AFSOR 89-D194 and OCAST \# HN 8-012.

\section{LITERATURE CITED}

BANDONI, S. M., AND D. W. DUSzYNSKI. 1988. A plea for improved presentation of type material for coccidia. The Journal of Parasitology 74: 519523.

Brandom, W. F., G. Saccomanno, V. E. Archer, P. G. ARChER, AND M. E. CoORS. 1972. Chromosome aberrations in uranium miners occupationally exposed to ${ }^{222}$ radon. Radiation Research 52: 204-215.

Chase, J. D., W. E. Howard, and J. T. Roseberry. 1984. Pocket gophers. In Wild mammals of North America, J. A. Chapman and G. A. Feldhammer (eds.). Johns Hopkins University Press, Baltimore, Maryland, pp. 239-255.

Daly, J. C., and J. L. Patton. 1990. Dispersal, gene flow, and allelic diversity between local populations of Thomomys bottae pocket gophers in the coastal ranges of California. Evolution 44 1283-1294.

DORNEY, R. S. 1962. Coccidiosis in Wisconsin cottontail rabbits in winter. The Journal of Parasitology 48: 276-279.

Duszynski, D. W., G. Eastham, and T. L. Yates 1982. Eimeria from jumping mice (Zapus spp.): A new species and genetic and geographic features of $\mathrm{Z}$. hudsonicus luteus. The Journal of Parasitology 68: 1146-1148.

FindLeY, J. S. 1987. The natural history of New Mexican mammals. University of New Mexico Press, Albuquerque, New Mexico, pp. 74-77.

Frey, J. K., T. L. Yates, D. W. DuszynSKi, W. L. Gannon, and S. L. Gardner. 1992. Designation and curatorial management of type host specimens (symbiotypes) for new parasite species. An invited critical comment. The Journal of Parasitology 78: 930-932.

Howard, W. E., AND H. E. ChILdS, JR. 1959. Ecology of pocket gophers with emphasis on Thomomys bottae mewa. Hilgardia 29: 277-358.

LAINSON, R. 1968. Parasitological studies in British Honduras III. Some coccidial parasites of mammals. Annals of Tropical Medicine and Parasitology 62: 252-259.

Leonard, A., M. Delpoux, J. Chameaud, G. DeCAT, AND E. D. LEONARD. 1981. Biological ef fects observed in mammals maintained in an area of very high natural radioactivity. Canadian Journal of Genetics and Cytology 23: 321-326.

Levine, N. D., V. IVENS, AND F. J. KRUIDENIER 1957. New species of Eimeria from Arizona rodents. The Journal of Protozoology 4: 80-88.

Manchengo, R. A., V. T. MCLemore, AND J. W.
Hawley. 1991. New Mexico radon survey, 1987-1989. Special Publication (unnumbered) New Mexico Environment Department, Santa Fe, New Mexico, 34 pp.

Nevo, E., Y. J. Kim, C. R. Shaw, and C. S. Thaeler, JR. 1974. Genetic variation, selection, and speciation in Thomomys talpoides pocket gophers. Evolution 28: 1-23.

PAtTon, J. L., AND J. H. Feder. 1981. Microspatial genetic heterogeneity in pocket gophers: Nonrandom breeding and drift. Evolution 35: 912920.

Pohl-Ruling, J., AND P. Fischer. 1979. The doseeffect relationship of chromosome aberrations to alpha irradiation in a population subjected to an increased burden of natural radioactivity. Radiation Research 80: 61-81.

Poncy, J., C. Walter, P. Fritsch, R. Masse, and J. LAFUMA. 1980. Delayed SCE frequency in rat bone-marrow cells after radon inhalation. In Pulmonary toxicology of respirable particles, Proceedings of the 19th Annual Hanford Life Sciences Symposium, C. L. Sanders, F. T. Cross, G. E. Gagle, and J. A. Mahaffey (eds.). Technical Information Center, United States Department of Energy, Washington, D.C., pp. 479-485

Ronca-Battista, M., P. Magno, and P. Nyberg. 1987. Interim protocols from screening and follow-up radon and radon-decay product measurements. United States Environmental Protection Agency, EPA-520/1-86-014, Washington, D.C., 25 pp.

SElf, S., D. E. Kirchner, AND J. A. Wolff. 1988. The El Cajete Series, Valles Caldera, New Mexico. Journal of Geophysical Research 93(B6): 6113-6127.

Seville, R. S., H. J. Harlow, N. L. Stanton, and M. L. WAGNER. 1992. Effects of eimerian (Apicomplexa: Eimeriidae) infections on nutrient assimilation in the Wyoming ground squirrel. The Journal of Parasitology 78: 881-885.

SKIDMORE, L. V. 1929. Note on a new species of coccidia from the pocket gopher (Geomys bursarius) (Shaw). The Journal of Parasitology 15: 183-184.

Sperlich, D., A. Karlik, AND E. Pohl. 1967. Studies on the mutation inducing effect of radon-222 in Drosophila melanogaster. Strahlentherapie 132: 105-112.

Stenstran, K., R. A. Bailey, and C. S. RytomaA. 1979. Cytogenetic investigation of people in Finland using household water with high natural radioactivity. Health Physics 36: 441-444.

Stout, C. A., AND D. W. Duszynski. 1983. Coccidia from kangaroo rats (Dipodomys spp.) in the western United States, Baja California, and northern Mexico with descriptions of Eimeria merriami sp. $\mathrm{n}$. and Isospora sp. The Journal of Parasitology 69: 209-214.

Upton, S. J., R. M. PitTs, C. T. MCAllister, AND 
R. B. Hollander. 1992. New host records for Eimeria geomydis Skidmore, 1929, from Geomys (Rodentia: Geomyidae) and redescription of the oocysts from Geomys bursarius. Texas Journal of Science 44: 95-98.

Wilber, P. G., B. Hanelt, B. VAN Horne, and D. W. DUSZYNSKI. 1994. Two new species and temporal changes in the prevalence of eimerians in a free-living population of Townsend's ground squirrels (Spermophilus townsendii) in Idaho. The Journal of Parasitology 80: 251-259.

ZAR, J. H. 1984. Biostatistical analysis, 2nd ed. Prentice Hall, Englewood Cliffs, New Jersey, pp. 390395.

Received for publication 10 March 1993. 